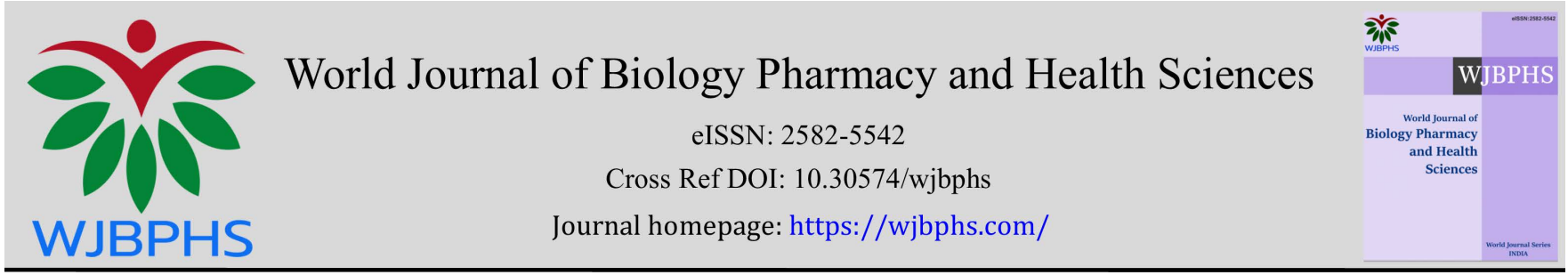

(RESEARCH ARTiCLE)

\title{
An investigation of the prevalence of COVID-19 among the tribal people of Bandarban hill district, Bangladesh
}

\author{
Farzana A Khan $1{ }^{,}$, Mohammad Alamgir ${ }^{2}$ and Ruhul A Khan ${ }^{3}$ \\ 1 UNFPA's support to 4th HPNSP through DGHS, Bandarban, Bangladesh. \\ ${ }^{2}$ Civil Surgeon Office, Bandarban, Bangladesh. \\ ${ }^{3}$ Institute of Radiation and Polymer Technology, Bangladesh Atomic Energy Commission, Dhaka, Bangladesh.
}

World Journal of Biology Pharmacy and Health Sciences, 2022, 09(02), 005-010

Publication history: Received on 21 December 2021; revised on 30 January 2022; accepted on 01 February 2022

Article DOI: https://doi.org/10.30574/wjbphs.2022.9.2.0029

\begin{abstract}
Tribal Peoples are always facing a wide range of socio-economic variance and are at uneven risk in public health emergencies even more vulnerable during this covid 19 pandemic worldwide. With a view to find out the COVID-19 infections and fatality rate among the different ethnic groups of peoples of the Bandarban Hill District (BHD), Bangladesh the current study was conducted. A hospital based cross-sectional study was carried out among purposively selected 989 ethnic inhabitants, suspected of the COVID-19 and took the diagnostic rRT-PCR test in different government hospital of Bandarban district of Chittagong Hill Tracts, Bangladesh during May to July, 2020. The mean age of the respondent was $35.35 \pm 14.33$ years where majority were adults and belongs to age group 18-55 years. Majority of the suspected cases were male (60\%) in relation to their counterpart. Among the suspected tribal people more than half (56\%) were Marma in origin followed by Bawm (9.8\%) and Tonchongya (9.6\%) and around three-fifth (59.6\%) were habitants of Bandarban Sadar. In laboratory rRT-PCR test results, $15.6 \%$ cases were found positive among the suspected cases tested for with $0.65 \%$ case fatality rate. The association between COVID-19 infection with the residing place of the respondents was found statistically significant $(\mathrm{p}=0.001)$. Though the COVID-19 infection among the tribal is lower than the national population, still the prevailing estimate is alarming and ask for further evaluation and community based awareness program and integrated health services need to recast to protect the ethnic group of people of the BHD, Bangladesh.
\end{abstract}

Keywords: COVID-19; Tribal; Pandemic; Bandarban; Bangladesh

\section{Introduction}

Since the end of world war two, the substantial challenge we have faced is the coronavirus COVID-19 pandemic, the prominent health crisis of our time. Since the emergence of COVID-19 in Asia, 2019 has been spread all over the world and every continent of the world except Antarctica [1]. To some extent people from every region of the world are affected by the corona virus disease pandemic. However, there is remarkable inequity for the 370 million tribal population of the world in terms of impact and threat of the disease [2]. The pandemic poses a huge threat to the ethnic minority around the world as they already ill-fated and suffering from higher rates of communicable and noncommunicable diseases, having poor access to health-care, essential services, sanitation and other key preventative measures [3]. Bangladesh is the homeland to over 54 different groups of tribal peoples (TPs) living in different corner of the country, which comprise approximately 1-2\% of the total population. The TPs have their distinct cultures, heritage and languages and primarily residing in the delta part of the country or "the plains", also in the South-Eastern corner of the country known as the Chittagong Hill Tracts (CHT) consisting of three districts namely Rangamati, Khagrachari and Bandarban [4]. COVID-19 is an infectious disease caused by severe acute respiratory syndrome

\footnotetext{
* Corresponding author: Farzana A Khan

UNFPA's support to 4th HPNSP through DGHS, Bandarban, Bangladesh.
} 
coronavirus-2 that was first identified in December 2019 in Wuhan, China and then spread globally and became pandemic [5]. According to the World Health Organization (WHO), in 05th June 2020, more than 6.8 million cases reported across 213 countries and 2 international conveyances and more than 400,000 deaths reported worldwide $[6,7]$. In Bangladesh the first case reported in $8^{\text {th }}$ March, 2020 in Dhaka city and 60,390 cases by $05^{\text {th }}$ June. The first case reported in Bandarban district in 21 ${ }^{\text {st }}$ April, 2020 and followed by first tribal infected case reported in $22^{\text {nd }}$ April, 2020. Following first case reported there was only one reported tribal infected case up to $1^{\text {st }}$ May, 2020 [8].

While the infected case of COVID-19 are increasing day by day worldwide with high mortality rates among different vulnerable group of people with underlying conditions, still the data on the rate of infection among ethnic minority population are either not yet available (even where reporting and testing are available) or not reported by ethnicity. Moreover, relevant information regarding preventive measures of the disease are not available in tribal languages. To protect the tribal population from COVID-19 infection data needs to be subdivided by ethnicity, since the sequence of SARS-CoV-2 analysis has showed that the virus genome sequence from different patients are very conserved [9]. With a view to find out the COVID-19 related data among the different ethnic group of people of Bandarban Hill District (BHD), the current study was carried out.

\section{Methods}

A hospital based cross sectional study was carried out to find out the infection rate of COVID-19 among the different tribal population residing in Bandarban district of Chittagong Hill Tracts. The data collection was carried out from May to July, 2020 among the ethnic minority suspected for the disease and took the diagnostic rRT-PCR test in the hospital settings of Sadar Upazila Health Complex, Lama Upazila Health Complex, Alikadam Upazila Health Complex, Naikhongchari Upazila Health Complex, Rowangchari Upazila Health Complex, Thanchi Upazila Health Complex, Ruma Upazila Health Complex and Sadar Hospital, Bandarban, Chattogram, Bangladesh. In total 989 people participated in the study after meeting the desired criterias for the study and after informed about the study. The participants were selected purposively and interviewed by trained research assistants through face to face interview by using a semistructured questionnaire. The test results were collected from the government authorized Institute of Epidemiology, Disease Control and Research (IEDCR) field laboratory, Cox's Bazar and Bangladesh Institute of Tropical and Infectious Disease (BITID) laboratory, Chattogram. The data were checked and cleaned followed by categorizing data, coded and post codes into IBM SPSS v25. The analysis was carried out by using both descriptive and inferential statistics and presented with tables and chart. The ethical approval and written permission for data collection was taken from the District Civil Surgeon Office, Bandarban. (Memo CS/B-Ban/MIS/COVID-19/2020/1333).

\section{Results}

Table 1 depicts the socio-demographic profile of the respondents of different group of tribal people residing in Bandarban district of the Chattogram Hill Tract. The mean age of the respondent was $35.35 \pm 14.33$ years, which belong to the middle age group. Around $80 \%$ suspected respondents were adult, from young adult to middle aged whereas only $8 \%$ were elderly. Though a small proportion, around $5 \%$ were children and teens, but it was alarming in terms of number. Male and female suspected cases ratio were almost 60:40 with male majority.

Table 1 Socio-demographic profile ( $\mathrm{n}=989)$

\begin{tabular}{|l|c|c|}
\hline & n & \% \\
\hline \multicolumn{2}{|c|}{ Age group (Years) } \\
\hline$\leq 12$ & 55 & 5.6 \\
\hline $13-17$ & 54 & 5.5 \\
\hline $18-35$ & 401 & 40.5 \\
\hline $36-55$ & 400 & 40.4 \\
\hline$\geq 56$ & 79 & 8.0 \\
\hline Mean \pm SD= 35.35 & & \\
\hline Sex 14.33 years \\
\hline Male & 591 & 59.8 \\
\hline Female & 398 & 40.2 \\
\hline
\end{tabular}




\begin{tabular}{|l|c|c|}
\hline \multicolumn{4}{|l|}{ Living place (Upazila) } \\
\hline Sadar & 589 & 59.6 \\
\hline Rowangchari & 110 & 11.1 \\
\hline Naikhongchari & 59 & 6.0 \\
\hline Ruma & 114 & 11.5 \\
\hline Thanchi & 61 & 6.2 \\
\hline Alikadam & 20 & 2.0 \\
\hline Lama & 31 & 3.1 \\
\hline Outsider & 5 & 0.5 \\
\hline
\end{tabular}

Figure 1 illustrates the proportion of different group of tribal population suspected of COVID-19 infection where majority (56.1\%) were Marma followed by Bawm and Tonchongya, both were around $10 \%$ followed by Chakma and Tripura. Around three-fifth (59.6\%) of the suspected cases were habitants of Bandarban Sadar followed by Ruma and Rowangchari, both were around $11 \%$ followed by Thanchi (6.2\%) and Naikhongchari Upazilla (6.0\%).

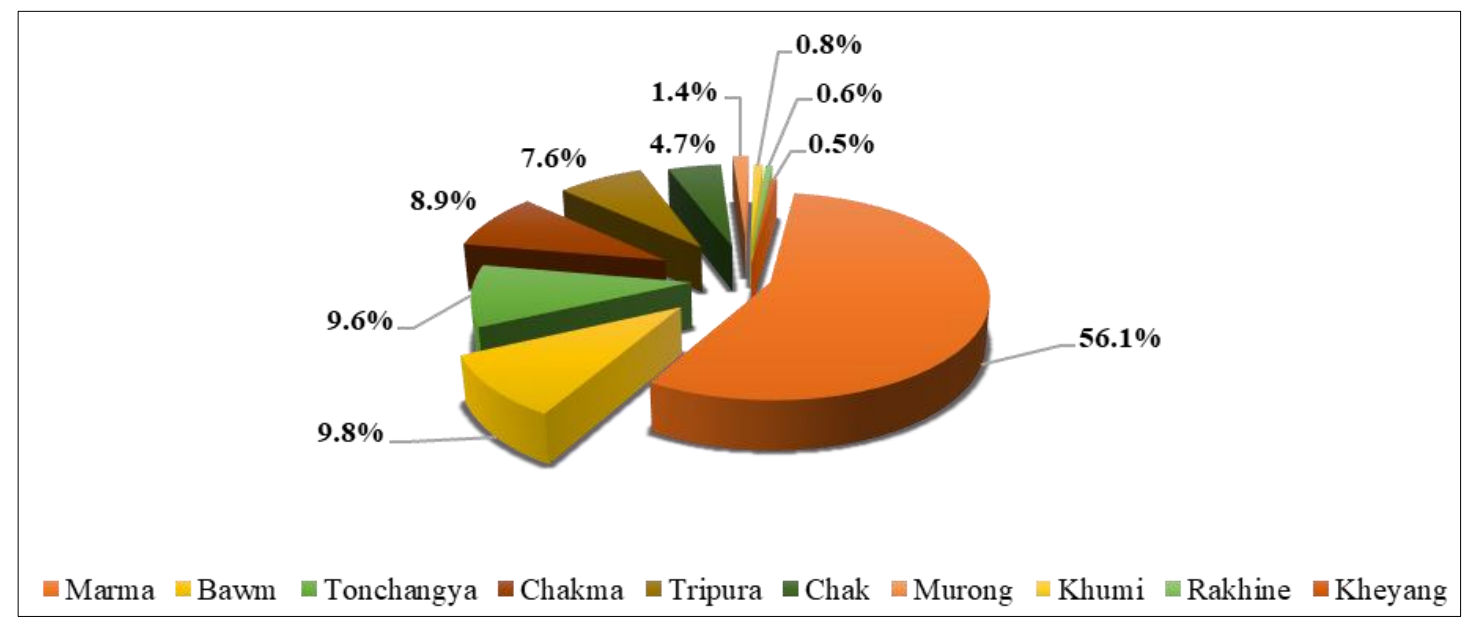

Figure 1 Ethnic origin Indigenous Tribal population (n=989)

Table 2 Period of detection and rRT-PCR test results ( $\mathrm{n}=989)$

\begin{tabular}{|c|c|c|}
\hline & $\mathbf{n}$ & $\%$ \\
\hline \multicolumn{3}{|l|}{ Month } \\
\hline May & 268 & 27.1 \\
\hline June & 363 & 36.7 \\
\hline July & 358 & 36.2 \\
\hline \multicolumn{3}{|l|}{ Results } \\
\hline Positive & 154 & 15.6 \\
\hline Negative & 835 & 84.4 \\
\hline \multicolumn{3}{|c|}{ Case fatality rate (CFR) } \\
\hline Total death & 01 & 0.65 \\
\hline
\end{tabular}

Table 2 demonstrates the period of detection and it shows most of them (73\%) were detected during June and July month of 2020. In laboratory rRT-PCR test results were positive for $15.6 \%$ population. Only one tribal (ethnic originMarma) death case was reported during the study period and the case fatality rate found $0.65 \%$. 
Table 3 Distribution of COVID-19 infection rate among the different group of TP (n=989)

\begin{tabular}{|c|c|c|c|c|c|c|c|c|}
\hline \multirow{2}{*}{$\begin{array}{l}\text { Socio- } \\
\text { demographic } \\
\text { profile }\end{array}$} & \multicolumn{8}{|c|}{ Aboriginal origin } \\
\hline & $\begin{array}{l}\text { Marma } \\
\text { N (\%) }\end{array}$ & $\begin{array}{l}\text { Bawm } \\
\text { N (\%) }\end{array}$ & $\begin{array}{l}\text { Tonchangya } \\
\text { N (\%) }\end{array}$ & $\begin{array}{l}\text { Chakma } \\
\text { N (\%) }\end{array}$ & $\begin{array}{l}\text { Tripura } \\
\text { N (\%) }\end{array}$ & $\begin{array}{l}\text { Chak } \\
\text { N (\%) }\end{array}$ & $\begin{array}{l}\text { Murong } \\
\text { N (\%) }\end{array}$ & $\begin{array}{l}\text { Khumi } \\
\text { N (\%) }\end{array}$ \\
\hline \multicolumn{9}{|c|}{ Age group (Years) } \\
\hline$\leq 12$ & $5(5.6)$ & $1(4.5)$ & - & $1(12.5)$ & - & - & $1(100)$ & - \\
\hline $13-17$ & $2(2.2)$ & $1(4.5)$ & $1(5.3)$ & - & - & - & - & $1(100)$ \\
\hline $18-35$ & $28(31.5)$ & $7(31.8)$ & $8(42.1)$ & $2(25.0)$ & $5(62.5)$ & $4(66.7)$ & - & - \\
\hline $36-55$ & $44(49.4)$ & $10(45.5)$ & $10(52.6)$ & $4(50.0)$ & $2(25)$ & $2(33.3)$ & - & - \\
\hline$\geq 56$ & $10(11.2)$ & $3(13.6)$ & - & $1(12.5)$ & $1(12.5)$ & - & - & - \\
\hline \multicolumn{9}{|l|}{ Sex } \\
\hline Male & $55(61.8)$ & $13(59.1)$ & $10(52.6)$ & $5(62.5)$ & $7(87.5)$ & $5(83.3)$ & $1(100)$ & - \\
\hline Female & $34(38.2)$ & $9(40.9)$ & $9(47.4)$ & $3(37.5)$ & $1(12.5)$ & $1(16.7)$ & - & $1(100)$ \\
\hline \multicolumn{9}{|c|}{ Living place (Upazila) } \\
\hline Sadar & $69(77.5)$ & $20(90.9)$ & $13(68.4)$ & $4(5)$ & $5(62.5)$ & $4(66.7)$ & - & - \\
\hline Rowangchari & $7(7.9)$ & $1(4.5)$ & $5(26.3)$ & $2(25)$ & - & - & - & - \\
\hline Naikhongchari & $3(3.4)$ & - & - & $1(12.5)$ & $1(12.5)$ & $2(33.3)$ & - & - \\
\hline Ruma & $3(3.4)$ & - & - & $1(12.5)$ & - & - & $1(100)$ & $1(100)$ \\
\hline Thanchi & - & - & - & - & $1(12.5)$ & - & - & - \\
\hline Alikadam & $5(5.6)$ & - & - & - & $1(12.5)$ & - & - & - \\
\hline Lama & $2(2.2)$ & - & $1(5.3)$ & - & - & - & - & - \\
\hline Outsider & - & $1(4.5)$ & - & - & - & - & - & - \\
\hline
\end{tabular}

Table 4 Association between rRT-PCR test results and Socio-demographic profile (n=989)

\begin{tabular}{|c|c|c|c|c|}
\hline \multirow[t]{2}{*}{ Socio-demographic profile } & \multicolumn{2}{|c|}{ rRT-PCR test results } & \multirow{2}{*}{$\chi^{2}$} & \multirow{2}{*}{ P-value } \\
\hline & Positive n (\%) & Negative n (\%) & & \\
\hline \multicolumn{5}{|l|}{ Age group (Years) } \\
\hline$\leq 12$ & $8(5.2)$ & $47(5.6)$ & \multirow{5}{*}{5.528} & \multirow{5}{*}{0.233} \\
\hline $13-17$ & $5(3.2)$ & $49(5.9)$ & & \\
\hline $18-35$ & $54(35.1)$ & $347(41.6)$ & & \\
\hline $36-55$ & $72(46.8)$ & $328(39.3)$ & & \\
\hline$\geq 56$ & $15(9.7)$ & $64(7.7)$ & & \\
\hline \multicolumn{5}{|l|}{ Sex } \\
\hline Male & $96(62.3)$ & $495(59.3)$ & \multirow{2}{*}{0.386} & \multirow{2}{*}{0.534} \\
\hline Female & $58(37.7)$ & $340(40.7)$ & & \\
\hline \multicolumn{5}{|l|}{ Aboriginal origin } \\
\hline Marma & $89(57.8)$ & $466(55.8)$ & \multirow{3}{*}{13.78} & \multirow{3}{*}{0.099} \\
\hline Bawm & $22(14.3)$ & $66(7.9)$ & & \\
\hline Tonchangya & $19(12.3)$ & $76(9.1)$ & & \\
\hline
\end{tabular}




\begin{tabular}{|c|c|c|c|c|}
\hline Chakma & $8(5.2)$ & $89(10.7)$ & & \\
\hline Tripura & $8(5.2)$ & $67(8.0)$ & & \\
\hline Chak & $6(3.9)$ & $40(4.8)$ & & \\
\hline Murong & $1(0.6)$ & $13(1.6)$ & & \\
\hline Khumi & $1(0.6)$ & $7(0.8)$ & & \\
\hline Rakhine & - & $6(0.7)$ & & \\
\hline Kheyang & - & $5(0.6)$ & & \\
\hline \multicolumn{5}{|c|}{ Living place (Upazila) } \\
\hline Sadar & $115(74.7)$ & $474(56.8)$ & \multirow{8}{*}{30.213} & \multirow{8}{*}{0.001} \\
\hline Rowangchari & $15(9.7)$ & $95(11.4)$ & & \\
\hline Naikhongchari & $7(4.5)$ & $52(6.2)$ & & \\
\hline Ruma & $6(3.9)$ & $108(12.9)$ & & \\
\hline Thanchi & $6(3.9)$ & $14(1.7)$ & & \\
\hline Alikadam & $3(1.9)$ & $28(3.4)$ & & \\
\hline Lama & $1(0.6)$ & $60(7.2)$ & & \\
\hline Outsider & $1(0.6)$ & $4(0.5)$ & & \\
\hline
\end{tabular}

Table 3 describes the distribution of COVID - 19 cases on the basis of their socio-demographic profile and different ethnic origin. The infection rate was highest among the Marma group of TP and among them middle aged (49.4\%), male $(61.8 \%)$ and residents of Bandarban Sadar $(77.5 \%)$ were mostly affected by the pandemic. Besides Marma, Bawm and Tonchangya were infected as second highest TP and followed the trends of Marma TP. Among Chakma 50\% were middle aged and were residents of Sadar. Tripura and Chak were noticeable as the young adult group was most affected rather than middle aged and most of them were male. No adult was infected among Murong and Khumi, rather than a single case of a child was found among Murong and a single teenager was found among Khumi.

Table 4 interprets the association of COVID-19 infection rate with the socio-demographic profile of the respondents. Majority of the COVID-19 infection found among the middle aged group of people (46.8\%). Majority of the male were affected (62.3\%) and habitants of the Bandarban Sadar (74.7\%). More than half of infected cases were Marma in terms of ethnic origin followed by Bawm, Tonchangya, Chakma, Tripura, Chak, Murong and Khumi respectively. Rakhaine and Kheyang group of TP was found COVID-19 infection free during the study period. The association between COVID-19 infections with the residing place of the respondents was found statistically significant $(\mathrm{p}=0.001)$.

\section{Discussion}

The limitation of the study is the current study includes only those symptomatic cases who came in contact with the hospital for diagnosis and treatment purpose. Moreover to overcome the language barrier precious few data was collected by an interpreter from the respondents. The study reveals the mean age of the respondent was $35.35 \pm 14.33$ years and majority of the respondents (80\%) belong to adult population and age was 18-55 years old. This group of people are found potentially vulnerable group due to their outside exposure for working and earning purpose which is found similar to both Bangladeshi populations as well as worldwide population data $[10,11]$. Majority of the respondents were male $(60 \%)$ than their counterpart. Though among the tribal population females are more active outside worker, but the suspected cases were higher among male which is similar to the other part of the country [10]. Study reveals majority of the respondents are Marma ethnic origin and residing in Sadar as the main ethnic nation of the district is Marma [12]. According to the current study, the positive infection rate found around $16 \%$ among the tribal population which is lower than the national positive infection rate which was around $20 \%$ during the study period. ${ }^{12}$ On top of that the case fatality rate was also lower than the national case fatality rate which was $0.64 \%$ and $1.31 \%$ respectively [13]. The study reveals the differences in infection rates of COVID-19 among the different group of the ethnic minority population of Bandarban district which was clearly higher among Marma followed by Bawm and Tonchangya. Moreover the study found a significant association between the COVID 19 infected cases and their residing place ( $\mathrm{p}=0.001)$ where majority was habitants of Sadar which is a densely populated territory of the district. 


\section{Conclusion}

The current study clearly depicts the alarming effects of covid 19 pandemic among the ethnic people of Bandarban district. Though the fatality rate is less among the tribals, still their infection rate is alarming based on their habitants. So it's a crying need to make them aware by providing covid 19 related information in their own language and ensure integrated community based health care services to protect them from this pandemic as well as maintain their own cultures and values. To find out the factors aggravating the attack rate of covid 19 among the tribals, further study evaluation is enjoined.

\section{Compliance with ethical standards}

\section{Acknowledgments}

The authors would like to thank all the participants participated in this study and also acknowledge the contribution of Sadia Ahmed Momo, Department of Civil Engineering, Chittagong University of Engineering and Technology, Chittagong, Bangladesh for her technical support. The authors also thanks to the research assistants and interpreter for their incredible works.

\section{Disclosure of conflict of interest}

Authors have no potential conflict of interest.

\section{Statement of informed consent}

Informed consent was obtained from all individual participants included in the study.

\section{References}

[1] COVID-19 pandemic: Humanity needs leadership and solidarity to defeat the coronavirus. [Internet]. United Nations Development Programme (UNDP). 2020.

[2] Power T, Wilson D, Best O, Brockie T, Bourque Bearskin L, Millender E, Lowe J. COVID-19 and Indigenous Peoples: An imperative for action. Journal of Clinical Nursing. 2020; 29(15-16): 2737-41.

[3] COVID-19 and Indigenous peoples. [Internet]. United Nation. 2020.

[4] Indigenous peoples in Bangladesh. [Internet].

[5] Palamim CV, Ortega MM, Marson FA. COVID-19 in the Indigenous Population of Brazil. Journal of Racial and Ethnic Health Disparities. 2020; 7(6): 1053-8.

[6] Worldometer: COVID-19 Update. [Internet].

[7] Coronavirus disease (COVID-19) pandemic. [Internet]. World Health Organization (WHO). 2021.

[8] Bangladesh Coronavirus update. [Internet].

[9] Lu R, Zhao X, Li J, Niu P, Yang B, Wu H, Wang W, Song H, Huang B, Zhu N, Bi Y. Genomic characterisation and epidemiology of 2019 novel coronavirus: implications for virus origins and receptor binding. The Lancet. 2020; 395(10224): 565-74.

[10] World Health Organization. Novel Coronavirus (2019-nCoV) : Situation Report 18. World Health Organization. 2020.

[11] World Health Organization. Novel Coronavirus (2019-nCoV): Situation Report 22. World Health Organization. 2020.

[12] Population and Housing Census 2011: Socio-Economic and Demographic Report. [Internet]. Bangladesh Bureau of Statistics (BBS). 2012. 